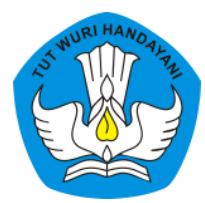

Page: 143-164

\title{
EKSPLORASI PENALARAN SPASIAL PADA KONSTRUK ROTASI MENTAL DENGAN MEDIA GOOGLE SKETCHUP
}

\author{
Khairul Akbar \\ Sekolah Menengah Pertama Negeri 2 Praya Barat Daya, Lombok Tengah, \\ Nusa Tenggara Barat, Indonesia \\ Contributor Email: khairulakbar17@guru.smp.belajar.id
}

Received: Jan 19, 2021

Accepted: Mar 10, 2021

Published: Mar 30, 2021

Article Url: https://ojsdikdas.kemdikbud.go.id/index.php/didaktika/article/view/203

\begin{abstract}
This study aimed to describe students' spatial thinking in the mental rotation mental rotation construct before and after exploring Google SketchUp media. This study is a qualitative approach and case study methods. Each participant was selected by two students with high, medium, and low mathematical abilities respectively. The instruments were written tests of mental rotation construct and interview guidelines. The research procedures were: (1) students worked on pre-test ; (2) initial interview; (3) students explored rotations activities with Google SketchUp; (4) student worked on post-test; (5) final interview. Results of the pre-test and initial interviews showed that students struggled to employ spatial reasoning in mental rotation construct for the cube rotation in all directions. The results of the post-test and the final interview showed that these six students were able to employ spatial reasoning in mental rotation construct for all indicators. Thus it is concluded that the use of Google Sketchup media can change the way of thinking of mental rotation constructs of spatial thinking.
\end{abstract}

Keywords: Spatial Reasoning; Mental Rotation Construct; Google SketchUp 


\begin{abstract}
Abstrak
Penelitian ini bertujuan untuk mendeskripsikan cara berpikir spasial siswa pada konstruk rotasi mental sebelum dan sesudah mengeksplorasi media Google SketchUp. Penelitian ini menggunakan pendekatan kualitatif dengan metode studi kasus. Subjek penelitian dipilih masing-masing dua orang siswa dengan kemampuan matematika tinggi, sedang, dan rendah. Instrumen penelitian adalah tes tertulis penalaran spasial konstruk rotasi mental dan pedoman wawancara. Prosedur penelitian adalah (1) siswa mengerjakan soal pre-test; (2) wawancara awal; (3) siswa melakukan eksplorasi rotasi dengan media Google SketchUp; (4) siswa mengerjakan soal posttest; (5) wawancara akhir. Hasil pre-test t dan wawancara awal menunjukkan siswa kesulitan melakukan penalaran spasial pada konstruk rotasi mental pada indikator rotasi segala arah dengan objek kubus. Hasil posttest dan wawancara akhir menunjukkan keenam siswa mampu melakukan penalaran spasial konstruk rotasi mental untuk semua indikator. Dengan demikian disimpulkan bahwa penggunaan media Google SketchUp dapat merubah cara berpikir spasial konstruk rotasi mental.
\end{abstract}

Kata Kunci: Penalaran Spasial; Konstruk Rotasi Mental; Google SketchUp.

\title{
A. Pendahuluan
}

Geometri adalah salah satu materi penting pada mata pelajaran matematika di jenjang Sekolah Menengah Pertama (SMP). Pada materi geometri, siswa dituntut untuk mampu menyelesaikan masalah yang berkaitan dengan bangun datar/dua dimensi maupun bangun ruang/tiga dimensi. Pada konteks dunia nyata, terdapat banyak permasalahan yang berhubungan dengan bangun dua dimensi dan tiga dimensi dimana permasalahan tersebut hanya dapat diselesaikan dengan geometri. Oleh karena itu, memahami materi geometri dengan baik dan benar menjadi sangat penting.

Namun sangat ironis, begitu pentingnya memahami geometri dengan baik dan benar ternyata tidak dibarengi dengan hasil belajar yang baik dari siswa di Indonesia. Berdasarkan hasil Ujian Nasional Matematika SMP tahun 2019 (grafik 1), diperoleh data bahwa persentase siswa yang menjawab benar pada materi "geometri dan pengukuran" pada tingkat nasional sebesar $42,27 \%$.

Hasil tersebut lebih rendah dibandingkan dengan dua materi lainnya yaitu "aljabar" dan "statistika dan peluang". Bahkan, pada tingkat 
satuan pendidikan SMP Negeri 2 Praya Barat Daya, Kabupaten Lombok Tengah, Provinsi Nusa tenggara Barat (NTB), prosentase siswa yang menjawab benar pada materi "geometri dan pengukuran" sebesar 32,11\% yang merupakan persentase paling rendah jika dibandingkan dengan tiga materi lainnya.

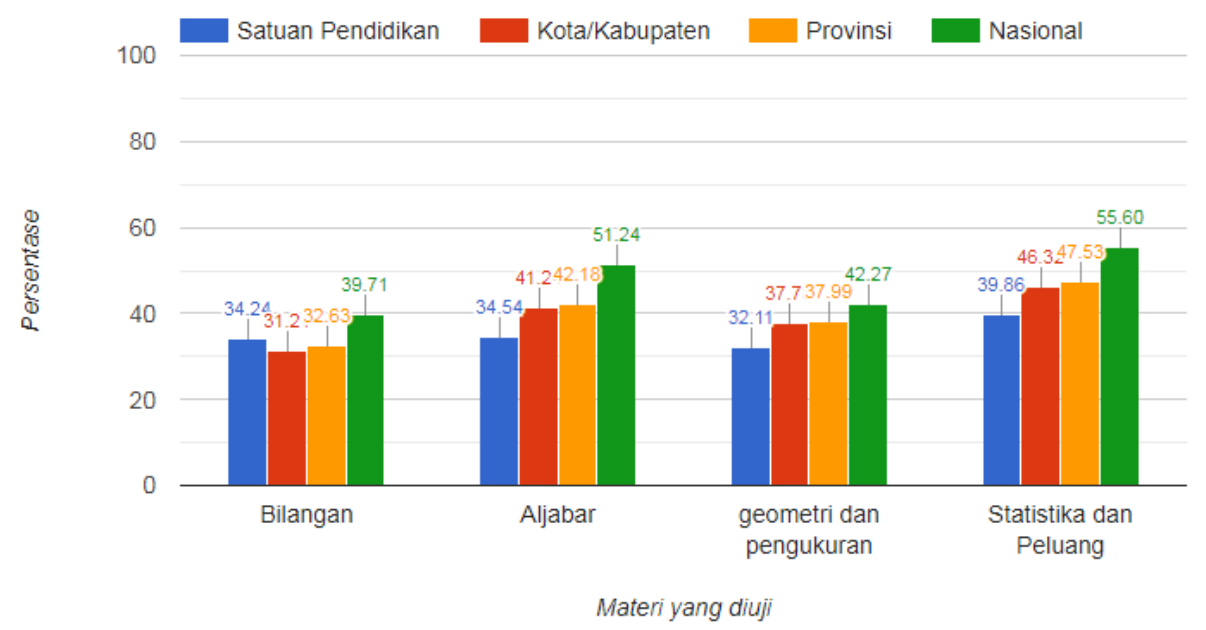

Diagram 1. Persentase Siswa yang Menjawab Benar pada Ujian Nasional (UN) Matematika SMP tahun 2019

(Sumber : https://pusmenjar.kemdikbud.go.id/hasil-un/)

Fakta tersebut tentu harus menjadi perhatian yang serius bagi guru mata pelajaran matematika di SMP Negeri 2 Praya Barat Daya. Guru mata pelajaran matematika harus mampu melakukan berbagai inovasi dalam pembelajaran geometri demi mengatasi permasalahan tersebut. Karakteristik materi geometri yang identik dengan bangun dua dimensi dan tiga dimensi tentu membutuhkan media pembelajaran yang mampu memvisualisasikan bangun tersebut. Hal ini sesuai dengan pernyataan Astawa (2018) bahwa untuk menjembatani antara konsep yang abstrak dengan nyata pada matematika dibutuhkan media pembelajaran. Selain itu, media pembelajaran juga memiliki peran untuk menarik perhatian siswa dalam belajar sehingga tertarik untuk mengikuti pembelajaran (Hotib, 2020).

NCTM (2000) menyatakan bahwa dalam belajar geometri siswa harus memiliki empat kemampuan, salah satunya adalah mampu 
memecahkan masalah dengan menggunakan penalaran spasial. Penalaran spasial adalah kemampuan membayangkan perubahan dunia visual spasial secara akurat. Kemampuan ini melibatkan kepekaan terhadap bangun dua dimensi maupun tiga dimensi (Amstrong, 2008). Lowrie et al. (2017) menyatakan bahwa penalaran spasial adalah kemampuan menginterpretasikan dan menavigasi objek di sekitar kita. Dari dua pendapat di atas dapat disimpulkan bahwa penalaran spasial adalah kemampuan seseorang untuk membayangkan perubahan objek dua dimensi maupun tiga dimensi jika dilakukan manipulasi seperti melipat, refleksi (dicerminkan) maupun rotasi (diputar).

Linn \& Petersen (1985) membagi penalaran spasial menjadi tiga jenis, yaitu (a) Spatial Perception (persepsi spasial), (b) Mental Rotation (rotasi mental), (c) Spatial Visualization (visualisasi spasial). Lowrie et al., (2017) memilah penalaran spasial menjadi tiga konstruk, yaitu: (a) Spatial Visualization (visualisasi spasial), (b) Mental Rotation (rotasi mental), (c) Spatial Orientation (orientasi spasial). Visualisasi spasial adalah kemampuan membayangkan perubahan/manipulasi benda dua dimensi menjadi tiga dimensi (Patahuddin et al., 2018). Rotasi mental adalah kemampuan membayangkan perubahan posisi objek dua dimensi dan tiga dimensi setelah diputar (rotasi) dengan pusat tertentu (Winarti \& Patahuddin, 2019). Orientasi spasial adalah kemampuan membayangkan objek dari posisi berbeda (Lowrie et al., 2017).

Salah satu penyebab kegagalan dalam pembelajaran matematika khususnya pada materi geometri adalah penggunaan media pembelajaran yang kurang sesuai dan kurang maksimal. Salah satu media yang dapat digunakan adalah media pembelajaran berbasis teknologi informasi dan komunikasi (TIK). Tujuan pembelajaran berbasis TIK adalah agar peserta didik menjadi termotivasi dan tidak mudah merasa bosan dan jenuh dalam pembelajaran di kelas (Mashuri, 2019). Selain itu, media pembelajaran berbasis TIK juga dapat membantu memudahkan pemahaman siswa terhadap materi pembelajaran yang disampaikan oleh 
guru dan juga dapat meningkatkan sikap positif siswa dalam mengikuti proses pembelajaran di sekolah (Apriandi \& Setyansah, 2017).

Salah satu media pembelajaran berbasis TIK yang dapat diterapkan dalam pembelajaran matematika adalah Google SketchUp. Google SketchUp adalah sebuah perangkat lunak yang dikembangkan oleh perusahaan Startup di Colorado pada tahun 1999 oleh Brad Schell. Google SketchUp adalah sebuah program pemodelan objek tiga dimensi yang yang digunakan oleh perencana di bidang bangunan sipil seperti arsitektur atau teknik sipil, pembuat film, game developer dan profesi sejenis lainnya.

Pemanfaatan Google SketchUp sebagai sarana untuk mengembangkan media pembelajaran yang praktis juga merupakan inovasi yang perlu dikembangkan oleh guru matematika. Telah banyak media pembelajaran yang dikembangkan oleh peneliti terdahulu. Sari \& Kurniawati, (2020) mengembangkan perangkat pembelajaran REACT berseting Think Talk Write dengan bantuan Google SketchUp pada materi "Bangun Ruang Sisi Datar" SMP. Hasil penelitian tersebut menunjukkan bahwa media pembelajaran tersebut mendapat respon yang positif baik oleh guru matematika maupun oleh siswa di sekolah tempat uji coba. Penelitian lain dilakukan oleh Lubis et al., (2020) yang mengembangkan video animasi pembelajaran Bangun Ruang Sisi Datar yang berorientasi pada kemampuan spasial. Hasil penelitiannya menunjukkan media pembelajaran tersebut dinyatakan efektif digunakan untuk mengembangkan berpikir spasial siswa. Berdasarkan hasil kedua penelitian tersebut, maka peneliti tertarik untuk melakukan penelitian tentang media Google Sketchup pada materi rotasi jenjang SMP.

Beberapa penelitian terdahulu lainnya juga menunjukkan dampak positif penggunaan Google SketchUp sebagai media pembelajaran pada kemampuan matematika siswa. Penelitian Erkoc et al., (2013) menunjukkan hasil bahwa penggunaan Google Sketchlp mampu meningkatkan kemampuan rotasi mental siswa. Penelitian Kurtulus \& Candas, (2010) menunjukkan hasil bahwa Google SketchUp efektif digunakan dalam pembelajaran geometri untuk meningkatkan kemampuan visualisasi spasial 
mahasiswa. Penelitian Nasution \& Sa'dijah, (2015) menunjukkan hasil bahwa media Google SketchUp sangat membantu siswa dalam memvisualisasikan bangun tiga dimensi dan mampu meningkatkan pemahaman siswa tentang bangun tiga dimensi. Penelitian Sunata, (2016) menunjukkan hasil bahwa pembelajaran dengan bantuan media Google SketchUp lebih efektif digunakan pada siswa dengan kemampuan rendah dan sedang.

Semua penelitian terdahulu yang sudah diuraikan di atas menggunakan pendekatan kuantitatif, sehingga tidak diperoleh data yang mendalam mengenai bagaimana gambaran cara berpikir spasial siswa khususnya pada konstruk rotasi mental. Penelitian ini menggunakan pendekatan kualitatif dengan tujuan untuk mengetahui cara berpikir spasial siswa pada konstruk rotasi mental sebelum dan setelah menggunakan media Google SketchUp.

\section{B. Metode}

Penelitian ini menggunakan pendekatan kualitatif dengan metode studi kasus. Penelitian dilaksanakan di SMP Negeri 2 Praya Barat Daya Kabupaten Lombok Tengah Provinsi Nusa Tenggara Barat, pada tanggal 6 Februari 2020. Peneliti merupakan guru Matematika di SMP Negeri 2 Praya Barat Daya. Subjek penelitian ditentukan menggunakan teknik sampling purposive, yaitu penentuan sampel dengan pertimbangan tertentu (Sugiyono, 2015). Subjek penelitian dipilih masing-masing dua orang siswa kelas VIII SMP Negeri 2 Praya Barat Daya yang memiliki kemampuan matematika tinggi, sedang, dan rendah. Penentuan kategori kemampuan matematika tinggi, sedang, dan rendah ditentukan berdasarkan rata-rata nilai Matematika selama menjadi siswa di SMP Negeri 2 Praya Barat Daya.

Teknik pengumpulan data pada penelitian ini adalah dengan teknik tes tertulis, dokumentasi dan wawancara mendalam. Instrumen penelitian terdiri dari soal tes tertulis dengan materi penalaran spasial pada konstruk rotasi mental dan pedoman wawancara. Soal pre-test dan post-test yang 


\section{Khairul Akbar}

digunakan dalam penelitian ini diadopsi dari modul diklat elektronik penalaran spasial (e-Pensa) yang disusun oleh Lowrie \& Patahuddin, (2018). Diklat tersebut telah diselenggarakan secara daring oleh Pusat Pengembangan dan Pemberdayaan Pendidik dan Tenaga Kependidikan (PPPPTK) Matematika Yogyakarta pada tanggal 23-31 Oktober 2018. Dalam kegiatan diklat tersebut, peneliti juga terlibat sebagai peserta diklat bersama 49 orang peserta lainnya. Jumlah butir soal yang digunakan pada penelitian ini adalah tiga butir yang mewakili setiap indikator.

Indikator soal nomor 1 adalah menguji kemampuan rotasi mental dua arah yaitu dengan searah jarum jam dan berlawanan arah jarum jam yang menggunakan objek dua dimensi/bangun datar. Adapun butir soal nomor 1 adalah:

Perhatikan gambar sepeda di bawah ini.

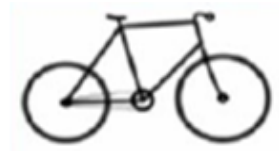

Hasil rotasi dari gambar di atas adalah ....

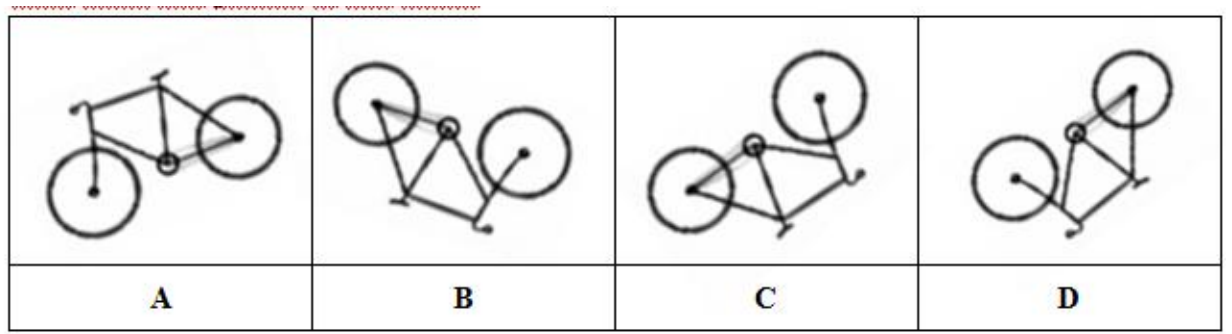

Indikator soal nomor 2 adalah menguji kemampuan rotasi mental segala arah yaitu arah kiri, kanan, depan, belakang, yang menggunakan objek bangun ruang gabungan beberapa kubus dengan salah satu kubus menonjol di bagian ujung tumpukan tersebut.

Adapun butir soal nomor 2:

Gambar di bawah ini menunjukkan model yang dibuat oleh beberapa kubus satuan. 


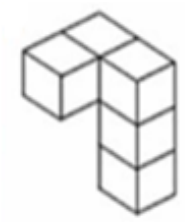

Berikut ini bangun yang sama dengan model di atas adalah....

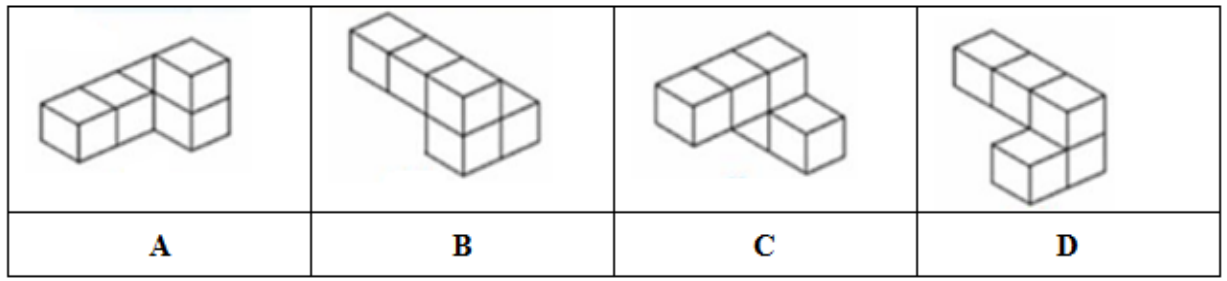

Indikator soal nomor 3 adalah menguji kemampuan rotasi mental segala arah yaitu kiri, kanan, depan, belakang, dan menggunakan objek bangun ruang kubus. Adapun butir soal nomor 3 adalah:

Anda diminta membandingkan dua kubus untuk menunjukkan apakah keduanya "SAMA" atau "TIDAK SAMA". Setiap sisi pada masing-masing kubus memiliki tanda berupa huruf yang berbeda.

a)

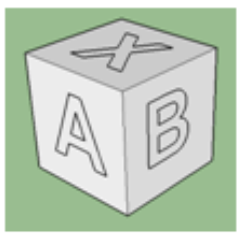

SAMA / TIDAK SAMA *)

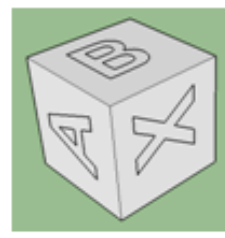

b)

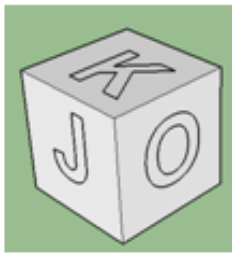

\section{SAMA / TIDAK SAMA *)}

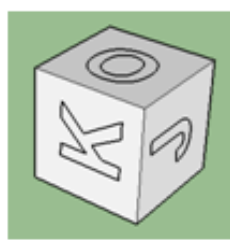

Prosedur penelitian diawali dengan pemberian soal pre-test kepada keenam subjek penelitian. Langkah kedua adalah wawancara awal kepada keenam subjek penelitian dengan tujuan untuk memperoleh gambaran tentang cara berpikir spasial siswa khususnya pada konstruk rotasi mental. Wawancara awal juga dimaksudkan sebagai konfirmasi kepada subjek penelitian mengenai cara berpikir spasial siswa ketika menjawab soal pre- 
test. Langkah ketiga adalah keenam subjek penelitian melakukan eksplorasi rotasi dengan menggunakan media Google SketchUp dengan bimbingan peneliti. Langkah keempat adalah keenam subjek penelitian mengerjakan soal posttes dengan bentuk dan isi soal post-test sama dengan soal pre-test . Langkah kelima adalah wawancara akhir dengan tujuan untuk memperoleh gambaran tentang cara berpikir spasial siswa khususnya pada konstruk rotasi mental setelah menggunakan media Google SketchUp.

Analisis data dilakukan dengan teknik Miles and Huberman, yaitu mulai dari data collection (pengumpulan data), data reduction (reduksi data), data display (penyajian data), dan conclusion drawing/verification (verifikasi) (Sugiyono, 2015).

\section{Hasil dan Pembahasan}

Lowrie et al., (2017) memilah penalaran spasial menjadi tiga konstruk, yaitu (a) visualisasi spasial (spatial visualization), (b) rotasi mental (mental rotation), dan (c) orientasi spasial (spatial orientation). Pada penelitian ini, fokus penelitian adalah penalaran spasial pada konstruk rotasi mental. Peneliti ingin mengetahui dan mendalami bagaimana cara berpikir spasial siswa sebelum dan sesudah menggunakan media Google SketchUp. Untuk menggali informasi tersebut, peneliti menggunakan teknik tes tertulis dan wawancara mendalam. Tes dan wawancara dilakukan kepada keenam subjek penelitian pada waktu sebelum dan sesudah melakukan eksplorasi media Google SketchUp. Tujuannya adalah untuk mengetahui apakah penggunaan media Google SketchUp berpengaruh terhadap cara berpikir spasial siswa.

Sebelum dilakukan penelitian, peneliti memberikan arahan kepada keenama subjek penelitian bahwa kegiatan yang akan dilakukan ini tidak ada hubungannya dengan pelajaran matematika di sekolah. Oleh karena itu, siswa yang terpilih sebagai sampel diharapkan menjawab dengan jujur dan apa adanya. Nilai yang diperoleh pada pre-test maupun post-test, tidak akan berpengaruh terhadap nilai pelajaran matematika di kelas. Hal ini penting dilakukan agar keenam subjek penelitian tidak 
merasa tertekan dengan kegiatan peneliti yang merupakan sekaligus sebagai guru matematika di sekolah.

Kegiatan pertama yang dilakukan pada penelitian ini adalah keenam subjek penelitian diminta untuk menjawab soal pre-test . Waktu yang disediakan untuk menjawab soal tersebut adalah selama 30 menit. Siswa diperbolehkan mencoret lembar soal jika diperlukan. Setelah subjek penelitian selesai menjawab soal pre-test, kegiatan penelitian dilanjutkan dengan wawancara awal. Wawancara awal bertujuan untuk memperoleh gambaran cara berpikir spasial siswa pada konstruk rotasi mental. Subjek penelitian diwawancarai sambil menunjukkan lembar jawaban pre-test untuk melakukan konfirmasi jawaban siswa. Wawancara awal dilakukan secara tertutup, artinya ketika wawancara dilakukan, maka siswa yang lain tidak boleh mendengar ataupun melihat kegiatan wawancara tersebut. Tujuannya adalah agar masing-masing siswa tidak terpengaruh oleh jawaban siswa yang lain sehingga diperoleh data yang benar-benar valid.

Adapun hasil jawaban pre-test soal nomor 1 oleh subjek penelitian menunjukkan keenam subjek penelitian mampu menjawab dengan benar. Berdasarkan hasil wawancara awal diperoleh keterangan bahwa cara berpikir keenam subjek penelitian sama yaitu dengan membayangkan objek pada soal tersebut diputar searah jarum jam. Siswa dengan kemampuan matematika sedang bahkan melakukan praktik rotasi dengan cara memutar lembar soal dengan tujuan untuk memastikan perubahan bentuk objek yang terdapat pada butir soal nomor 1 .

Jawaban pre-test soal nomor 2 adalah keenam subjek penelitian mampu menjawab dengan benar. Berdasarkan hasil wawancara awal diperoleh keterangan bahwa cara berpikir keenam subjek penelitian sama yaitu dengan membayangkan setiap objek pada pilihan A,B,C,D diputar sedemikian rupa sehingga posisi objek tersebut menjadi berdiri sesuai dengan posisi objek yang terdapat pada butir soal. Setelah objek tersebut berdiri, objek tersebut diputar. Selanjutnya membandingkan posisi kubus dua satuan yang terdapat pada soal dengan yang terdapat pada pilihan 


\section{Khairul Akbar}

jawaban. Keenam subjek penelitian menganggap kubus dua satuan tersebut sebagai kunci sehingga memudahkan untuk menandai bentuk pada objek tersebut.

Jawaban pre-test soal nomor 3a adalah kedua siswa dengan kemampuan matematika tinggi yang mampu menjawab dengan benar. Berdasarkan hasil wawancara awal diperoleh keterangan bahwa cara berpikir siswa dengan kemampuan matematika tinggi adalah dengan cara membayangkan kubus tersebut diputar ke kanan, sehingga dapat ditentukan posisi sisi " $X$ " yang seharusnya berada di bagian bawah, Namun kenyataannya posisi sisi " $X$ " pada kubus sebelah kiri adalah berada di bagian atas. Dengan demikian kedua siswa tersebut menyimpulkan bahwa kedua kubus tidak sama.

Jawaban soal nomor 3a untuk empat siswa dengan kemampuan matematika sedang dan rendah adalah mereka tidak mampu menjawab dengan benar. Berdasarkan hasil wawancara awal diperoleh keterangan bahwa cara berpikir keempat siswa tersebut adalah dengan membandingkan sisi-sisi kubus yang berada di sebelah kiri dengan kubus yang berada di sebelah kanan. Pada kedua kubus tersebut, keempat siswa berpikir bahwa terdapat salah satu sisi yang letaknya sama, yaitu sisi dengan huruf " $\mathrm{A}$ ", sedangkan sisi yang lain tidak terlalu berpengaruh. Dengan demikian keempat siswa tersebut menyimpulkan bahwa kedua kubus adalah sama.

Jawaban pre-test soal nomor $3 \mathrm{~b}$ adalah dua siswa dengan kemampuan matematika tinggi yang mampu menjawab dengan benar. Berdasarkan hasil wawancara awal diperoleh keterangan bahwa cara berpikir kedua siswa dengan kemampuan matematika tinggi tersebut adalah dengan membayangkan memutar kubus yang berada di sebelah kiri, maka semua sisi pada kedua kubus tersebut akan menempati posisi yang sama. Dengan demikian kedua siswa tersebut menyimpulkan bahwa kedua kubus adalah sama.

Jawaban soal nomor $3 \mathrm{~b}$ untuk empat siswa dengan kemampuan matematika sedang dan rendah tidak mampu menjawab soal dengan benar. 
Berdasarkan hasil wawancara awal diperoleh keterangan bahwa cara berpikir keempat siswa tersebut adalah dengan membandingkan sisi-sisi pada kubus yang berada di sebelah kiri dengan kubus yang berada di sebelah kanan. Keempat siswa berpikir bahwa tidak terdapat satu pun sisi yang seletak sehingga keempat siswa menganggap kedua kubus tersebut tidak sama.

Berdasarkan hasil analisis jawaban pre-test dan wawancara awal di atas, kedua siswa dengan kemampuan matematika tinggi sudah mampu melakukan penalaran spasial pada konstruk rotasi mental dengan baik. Kedua siswa tersebut tidak membutuhkan media dan juga tidak melakukan peragaan dalam melakukan penalaran spasial. Kedua siswa tersebut melakukan penalaran spasial cukup dengan membayangkan saja.

Sedangkan dua siswa dengan kemampuan matematika sedang dan dua siswa dengan kemampuan rendah hanya mampu melakukan penalaran spasial pada konstruk rotasi mental dua arah dan segala arah dengan objek bangun ruang gabungan. Namun mereka tidak mampu melakukan rotasi mental segala arah pada objek kubus. Menurut keempat siswa tersebut, melakukan penalaran spasial pada konstruk rotasi mental segala arah dengan objek kubus memiliki tantangan kesulitan yang lebih besar jika dibandingkan dengan objek bangun ruang gabungan. Siswa menganggap bahwa kubus adalah bangun ruang dengan sisi yang homogen sehingga sulit untuk melakukan penandaan/pengodean pada bagian-bagian tertentu pada objek tersebut, seperti yang dilakukan pada soal nomor 2 yaitu pemberian kode dilakukan dengan melakukan penandaan pada ujung bangun dengan satu kubus satuan dan ujung yang lain kubus tiga satuan. Faktor inilah yang menyebabkan keempat siswa dengan kemampuan matematika sedang dan rendah merasa kesulitan untuk melakukan penalaran spasial pada konstruk rotasi mental.

Setelah dilakukan wawancara awal tersebut, kegiatan penelitian selanjutnya adalah eksplorasi rotasi mental dengan Google SketchUp. Pada kegiatan ini, keenam subjek penelitian diberikan pembelajaran/pelatihan eksplorasi rotasi objek dua dimensi dan tiga dimensi dengan menggunakan 
media Google SketchUp. Pemilihan Google SketchUp sebagai media pembelajaran untuk melakukan rotasi adalah karena beberapa keunggulan, yaitu (1) Google SketchUp mampu memberi tampilan yang baik terhadap objek tiga dimensi/bangun ruang yang digambar sehingga menyerupai objek nyata; (2) Google SketchUp dapat dijalankan secara luring sehingga dapat dipergunakan di mana saja, cukup dengan melakukan meng-install di komputer; (3) Google SketchUp memiliki "tools" yang dapat digunakan untuk memutar objek (rotasi). Berdasarkan keunggulan tersebut diyakini bahwa penggunaan Google SketchUp sebagai media pembelajaran tersebut sangat sesuai digunakan pada eksplorasi kemampuan penalaran spasial siswa, khususnya pada konstruk rotasi mental.

Eksplorasi rotasi mental dengan media Google Sketchup diawali peneliti dengan menunjukkan cara memulai penggunaan Google Sketchup dan pengenalan tools. Selanjutnya mengenalkan cara menggambar bangun persegi/persegi panjang, insert gambar dua dimensi pada bangun persegi/persegi panjang yang telah digambar tersebut, melakukan manipulasi rotasi searah dan berlawanan arah jarum jam. Kegiatan berikutnya adalah peneliti menunjukkan cara menggambar bangun ruang kubus, dilanjutkan dengan insert huruf/angka di semua sisi kubus yang telah digambar tersebut, dan selanjutnya melakukan rotasi/memutar kubus tersebut. Keenam subjek penelitian secara bergiliran diberi kesempatan untuk melakukan eksplorasi rotasi mental dengan media Google SketchUp tersebut dengan alokasi waktu masing-masing siswa 15-20 menit.

Hasil praktik eksplorasi rotasi mental dengan media Google SketchUp oleh keenam subjek penelitian menunjukkan bahwa siswa dengan kemampuan matematika tinggi dan sedang terlihat cukup mudah untuk menggambar dan menggunakan "tools", namun siswa dengan kemampuan matematika rendah sedikit mengalami kesulitan di beberapa bagian kegiatan, seperti pada saat melakukan insert huruf pada sisi kubus. Siswa dengan kemampuan matematika rendah juga terlihat kurang teliti karena menganggap semua sisi kubus telah diberi huruf, padahal terdapat sisi yang belum diberi huruf yaitu sisi pada bagian bawah kubus. 
Siswa tersebut menganggap bahwa sisi pada bagian bawah kubus tidak terlihat walaupun sudah dirotasi beberapa kali. Pada saat siswa melakukan insert huruf di semua sisi kubus inilah secara tidak sadar siswa telah melakukan praktik rotasi. Proses ini diharapkan mampu meningkatkan kemampuan penalaran spasial siswa khususnya pada konstruk rotasi mental.

Sebelum Dilakukan Rotasi

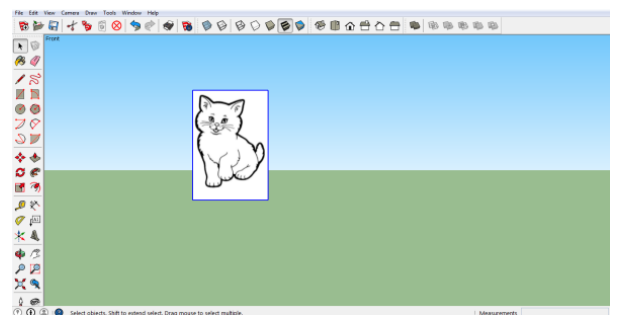

Setelah Dilakukan Rotasi

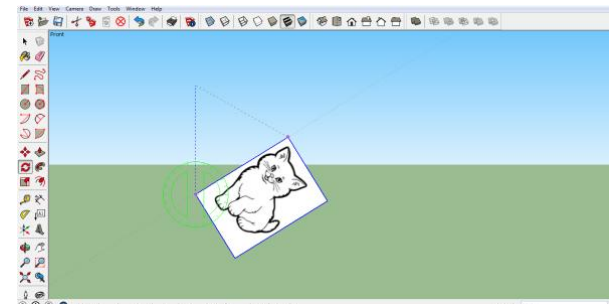

Gambar 1. Tampilan Perubahan Objek Dua Dimensi Sebelum dan Setelah Dirotasi Dua Arah pada Layar Media Google SketchUp

Gambar 1 menyajikan tampilan layar media Google SketchUp hasil eksplorasi siswa dalam melakukan rotasi objek dua dimensi dengan dua arah. Kegiatan awal siswa pada praktik melakukan rotasi pada media Google SketchUp adalah dengan melakukan import gambar sebagai objek rotasi. Secara aktif peneliti juga mendampingi dan membimbing siswa dalam melakukan kegiatan tersebut. Selanjutnya objek tersebut dirotasi dua arah yaitu searah jarum jam dan juga berlawanan arah jarum jam. Tampak pada Gambar 1 perubahan objek setelah dilakukan rotasi searah jarum jam. Temuan menarik dari gestur tubuh keenam siswa tersebut pada saat melakukan rotasi objek adalah adanya pergerakan/perputaran kepala siswa mengikuti arah perputaran objek. Ketika peneliti menanyakan tentang penyebab gerakan kepala tersebut, jawaban subjek penelitian adalah sebenarnya mereka tidak menyadari gerakan kepala tersebut akibat dari mengikuti perputaran objek.

Tampilan layar media Google SketchUp hasil eksplorasi siswa dalam melakukan rotasi objek tiga dimensi dengan rotasi segala arah disajikan pada Gambar 2. Kegiatan ini dilakukan setelah melakukan 
kegiatan pada Gambar, karena kegiatan ini membutuhkan kemampuan yang lebih tinggi dibandingkan dengan pada kegiatan sebelumnya. Kegiatan awal siswa adalah menggambar objek kubus/dadu. Selanjutnya, dadu tersebut diberi nomor 1-6. Siswa diberikan waktu dan kesempatan untuk lebih leluasa melakukan modifikasi nomor tersebut. Setelah kubus yang digambar tersebut lengkap, langkah selanjutnya adalah kubus tersebut diputar ke segala arah dengan titik pusat perputaran pada titik tertentu. Tampak pada Gambar 2 perubahan objek sebelum dan setelah dilakukan perputaran/rotasi.

Sebelum Dilakukan Rotasi

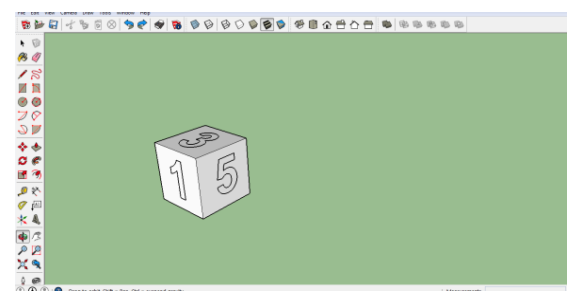

Setelah Dilakukan Rotasi

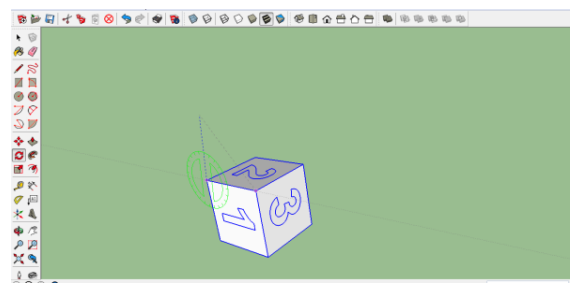

Gambar 2. Tampilan Perubahan Objek Tiga Dimensi Sebelum dan Setelah Dirotasi Segala Arah pada Layar Media Google Sketchup

Setelah keenam subjek penelitian tersebut melakukan eksplorasi rotasi mental dengan media Google SketchUp, maka kegiatan selanjutnya adalah pemberian post-test. Keenam subjek penelitian diminta kembali menjawab soal yang sama dengan soal pre-test . Pada saat mengerjakan post-test, ditekankan kepada keenam subjek penelitian agar ketika mebayangkan rotasi, keenam subjek penelitian menerapkan kemampuan rotasi yang telah diperoleh pada saat melakukan eksplorasi rotasi mental dengan media Google SketchUp sebelumnya.

Setelah selesai post-test, kegiatan selanjutnya adalah wawancara akhir. Wawancara akhir bertujuan untuk menggali cara berpikir spasial siswa dan mengetahui pengaruh media Google SketchUp dalam berpikir spasial. Wawancara ini juga bertujuan sebagai konfirmasi kepada keenam subjek penelitian terhadap cara mereka berpikir spasial ketika mengerjakan 
post-test. Wawancara dilakukan secara tertutup dan tidak dapat dilihat dan didengar oleh siswa yang lain. Wawancara tersebut direkam dengan dengan bantuan gawai/gadget. Video hasil wawancara akhir dan hasil posttest selanjutnya dianalisis untuk mendapatkan gambaran tentang cara berpikir spasial siswa khususnya pada rotasi mental.

Hasil analisis jawaban post-test pada soal nomor 1 menunjukkan bahwa keenam subjek penelitian mampu menjawab soal dengan benar. Hasil wawancara mendalam menunjukkan bahwa cara berpikir keenam subjek penelitian ketika menjawab soal nomor 1 adalah dengan cara membayangkan objek yang terdapat pada butir soal diputar searah jarum jam dengan pusat putaran di titik tertentu. Titik tertentu yang dimaksud di sini adalah di sembarang titik. Setiap siswa memilih titik pusat perputaran yang berbeda-beda.

Hasil analisis jawaban post-test soal nomor 2 menunjukkan bahwa keenam subjek penelitian mampu menjawab soal dengan benar. Hasil wawancara mendalam menunjukkan bahwa cara berpikir keenam subjek penelitian ketika menjawab soal nomor 2 adalah dengan membayangkan setiap objek pada pilihan A,B,C,D yang diputar sedemikian rupa agar posisi objek tersebut menjadi berdiri sesuai dengan posisi objek yang terdapat pada butir soal. Setelah objek tersebut berdiri, selanjutnya diputar dan kemudian dibandingkan posisi kubus dua satuan antara gambar pada butir soal dengan gambar pada pilihan jawaban.

Hasil analisis jawaban post-test soal nomor 3a menunjukkan bahwa keenam subjek penelitian mampu menjawab soal dengan benar. Hasil wawancara mendalam menunjukkan bahwa cara berpikir keenam subjek penelitian ketika menjawab soal nomor 3a adalah dengan membayangkan memutar salah satu kubus dan kemudian membandingkan posisi tiap sisi kubus antara kubus yang di sebelah kiri dengan kubus yang di sebelah kanan.

Hasil analisis jawaban post-test soal nomor 3b menunjukkan bahwa keenam subjek penelitian mampu menjawab soal dengan benar. Hasil wawancara mendalam menunjukkan bahwa cara berpikir keenam subjek 


\section{Khairul Akbar}

penelitian ketika menjawab soal nomor $3 b$ adalah dengan cara membayangkan memutar salah satu kubus, kemudian membandingkan posisi tiap sisi kubus antara kubus di sebelah kiri dengan kubus di sebelah kanan.

Berdasarkan analisis hasil wawancara akhir subjek penelitian diperoleh data bahwa subjek penelitian dengan kemampuan matematika tinggi tidak banyak melakukan perubahan cara berpikir dalam menjawab soal tersebut. Ini disebabkan kemampuan penalaran spasial yang dimiliki sejak awal sebelum berinteraksi dengan Google SketchUp sudah baik. Data penelitian diperoleh dari siswa dengan kemampuan matematika sedang dan rendah menunjukkan bahwa keempat siswa tersebut menjelaskan kesalahan yang dilakukan dalam menjawab soal pre-test nomor 3 dan melakukan perbaikan pada saat mengerjakan soal post-test. Siswa merasa terbantu dengan telah melakukan kegiatan eksplorasi rotasi dengan media Google SketchUp. Pernyataan siswa ini menjadi temuan penting karena dengan melakukan eksplorasi rotasi mental dengan media Google SketchUp, ternyata siswa mampu melakukan refleksi untuk mengetahui kesalahan dan kemudian melakukan perbaikan semestinya.

Berdasarkan hasil pre-test dan post-test diperoleh data bahwa terjadi kenaikan hasil tes siswa. Siswa dengan kemampuan matematika tinggi mampu menjawab dengan benar pada semua soal pre-test dan posttest. Siswa dengan kemampuan matematika sedang dan rendah, pada pretest mampu menjawab dengan benar pada soal nomor 1 dan 2, namun tidak mampu menjawab dengan benar pada soal nomor $3 a$ dan $3 \mathrm{~b}$. Pada post-test, siswa dengan kemampuan matematika sedang dan rendah mampu menjawab semua soal dengan benar.

Hasil wawancara juga menunjukkan bahwa siswa dengan kemampuan matematika sedang dan rendah tersebut mengetahui kesalahan cara melakukan penalaran spasial pada konstruk rotasi mental setelah melakukan eksplorasi Google SketchUp. Dengan demikian, dapat disimpulkan bahwa terdapat peningkatan kemampuan penalaran spasial pada konstruk rotasi mental terutama pada objek bangun ruang dengan 
rotasi segala arah setelah siswa melakukan eksplorasi dengan media Google SketchUp pada siswa dengan kemampuan matematika sedang dan rendah.

Hasil penelitian ini mendukung hasil penelitian Nasution \& Sa'dijah (2015) yang menunjukkan hasil bahwa media Google SketchUp sangat membantu siswa dalam memvisualisasikan bangun tiga dimensi dan dapat meningkatkan pemahaman siswa tentang bangun tiga dimensi. Efektivitas Google SketchUp untuk meningkatkan kemampuan spasial dengan kemampuan rendah dan sedang sejalan dengan hasil penelitian Sunata, (2016) dan Kurtulus (2011). Hasil penelitian ini juga menguatkan hasil penelitian Erkoc et al., (2013) bahwa penggunaan Google SketchUp dapat meningkatkan kemampuan rotasi mental siswa. Selain itu, temuan bahwa Google SketchUp sejalan dengan hasil penelitian Baki et al., (2011) bahwa perangkat lunak geometri dinamis yang berbasis TIK mampu meningkatkan mental siswa. Dikaitkan dengan pengembangan karir, hasil penelitian ini sejalan dengan hasil penelitian Uttal et al., (2013) yang menunjukkan bahwa meningkatkan kemampuan penalaran spasial siswa berpengaruh positif pada kesuksesan berkarir di bidang STEM (Science, Technology, Engineering, Mathematics). Oleh karena itu, pertumbuhan profesi di bidang STEM diproyeksikan akan berkembang lebih tinggi dibandingkan dengan bidang lain (Seameo Regional Centre For Qitep in Mathematics, 2018). Dengan demikian pembelajaran matematika khususnya pada materi geometri penting untuk diintegrasikan dengan pembelajaran penalaran spasial.

\section{Penutup}

Berdasarkan hasil penelitian, dapat disimpulkan bahwa cara berpikir spasial siswa sebelum dan sesudah menerapkan media Google SketchUp berbeda. Cara berpikir spasial siswa sesudah melakukan eksplorasi dengan Google SketchUp menjadi lebih baik daripada sebelum melakukan ekplorasi dengan Google SketchUp. Pada siswa dengan kemampuan tinggi, penggunaan media Google SketchUp tidak berpengaruh terhadap cara berpikir spasial pada konstruk rotasi mental. Perubahan cara berpikir spasial pada siswa dengan kemampuan matematika sedang dan rendah tersebut dapat meningkatkan 
kemampuan penalaran spasial pada konstruk rotasi mental. Hal ini disebabkan dengan menggunakan media Google SketchUp, siswa dapat melakukan manipulasi objek dan melihat perubahan objek tersebut setelah dilakukan rotasi. Visualisasi perubahan objek tersebut telah mengubah cara berpikir spasial siswa.

\section{Ucapan Terima Kasih}

Terima kasih saya ucapkan kepada Kepala Sekolah, guru matematika, dan siswa SMPN2 Praya Barat Daya yang telah mendukung dan membantu pelaksanaan penelitian ini.

\section{Daftar Referensi}

Amstrong, T. (2008). Multiple Intelligences in The Classroom. Alezandria: ASCD.

Apriandi, D., \& Setyansah, R. K. (2017). Penerapan Media Simulasi Matlab Berbasis Interactive Coceptual untuk Meningkatkan Pemahaman Konsep Mahasiswa. Aksioma Jurnal Pendidikan Matematika FKIP Univ. Muhammadiyah Metro, 6(2), 159-167. https://doi.org/10.24127/ajpm.v6i2.968.

Astawa, I. G. L. G. P. (2018). Pembelajaran Temuan Terbimbing Berbantuan Manik Android: Motivasi dan Hasil Belajar Operasi Hitung Bilangan Bulat. Jurnal Didaktika Pendidikan Dasar, 2(2), 341-356.

Baki, A., Kosa, T., \& Guven, B. (2011). A Comparative Study of The Effects of Using Dynamic Geometry Software and Physical Manipulatives on The Spatial Visualization Skills of Pre-service Mathematics Teachers. British Journal of Educational Technology, 42(2), 291-310. https://doi.org/https://doi.org/10.1111/j.1467-8535.2009.01012.x

Erkoc, M. F., Gecu, Z., \& Erkoz, C. (2013). The Effects of Using Google SketchUp on The Mental Rotations Skills of Eight Grade Students. Educational Sciences: Theory and Practice, 13(2), 1285-1294.

Hotib, T. A. (2020). Penggunaan Model Jigsaw Berbantuan Media Geoboard untuk Meningkatkan Hasil Belajar Matematika. Jurnal Didaktika Pendidikan Dasar, 4(1), 93-116. https://doi.org/10.26811/didaktika.v4i1.133. 
Kurtulus, A. (2011). Effect of Computer-aided Perspective Drawings on Spatial Orientation and Perspective Drawing Achievement. Turkish Online Journal of Educational Technology - TOJET, 10(4), 138-147.

Kurtulus, A., \& Candas, U. (2010). The Effects of Google Sketchup Based Geometry Activities and Projects on Spatial visualization Ability of Student Mathematics Teachers. Procedia-Social and Behavioral Sciences, 9, 384-389. https://doi.org/10.1016/j.sbspro.2010.12.169.

Linn, M. C., \& Petersen, A. C. (1985). Emergence and Characterization of Sex Differences in Spatial Ability: A Meta-Analysis. Child Development, 1479-1498.

Lowrie, T., Logan, T., \& Ramful, A. (2017). Visuospatial Training Improves Elementary Students' Mathematics Performance. British Journal of Educational Psychology, 87(2), 170-186. https://doi.org/10.1111/bjep.1214.

Lowrie, T., \& Patahuddin, S. M. (2018). Pengenalan Penalaran Spasial. Tidak Diterbitkan.

Lubis, S., Andayani, S., \& Habibullah, H. (2020). Pengembangan Video Animasi Pembelajaran Bangun Ruang Sisi Datar Berorientasi Pada Kemampuan Spasial. AKSIOMA: Jurnal Program Studi Pendidikan Matematika, 9(3), 822-832. https://doi.org/10.24127/ajpm.v9i3.3017.

Mashuri, S. (2019). Media Pembelajaran Matematika. Yogyakarta: Deepublish.

Nasution, S. H., \& Sa'dijah, C. (2015). Pemahaman Konsep Jarak pada Topik Tiga Dimensi Kelas X Menggunakan Model Pembelajaran Langsung Berbantuan Google SketchUp. Indonesian Digital Journal of Mathematic and Education, 2(2), 81-90.

NCTM. (2000). Principle and standards for school mathematics. Reston, Va: NCTM.

Patahuddin, S., Logan, T., \& Ramful, A. (2018). Characteristics of Spatial Visualisation: Perspectives from Area of Composite Shapes. Mathematics Education Research Group of Australasia, 623-630.

Sari, A. C., \& Kurniawati, N. (2020). Pengembangan Perangkatan Pembelajaran REACT Berseting Think Talk Writedengan Bantuan Google SketchUp pada Materi Bangun Ruang Sisi Datar SMP. Journal of Medives: Journal of 


\section{Khairul Akbar}

Mathematics Education IKIP Veteran Semarang, 4(1), 141-149. https:// doi.org/10.31331/medivesveteran.v4i1.986.

Seameo Regional Centre For Qitep in Mathematics. (2018). Learning Material In Country Course On STEM Education For Junior High School Mathematics Teachers. Yogyakarta: Seaqim.

Sugiyono. (2015). Metode Penelitian Kuantitatif, Kualitatif, dan RED (22nd ed.). Bandung: Alfabeta.

Sunata. (2016). Penggunaan Program Google SketchUp dalam Pembelajaran Geometri untuk Meningkatkan Kemampuan Komunikasi Matematika Siswa. Jurnal Ilmiah Pendidikan Dasar, 1(1), 129-139. https://doi.org/10.23969/jp.v1i1.288.

Uttal, D. H., Miller, D. I., \& Newcombe, N. S. (2013). Exploring and Enhancing Spatial Thinking Links to Achievement in Science, Technology, Engineering, and Mathematics? Current Directions in $\begin{array}{lll}\text { Psychological } \quad \text { Science, } & \text { 22(5), }\end{array}$ https://doi.org/10.1177/0963721413484756.

Winarti, D. W., \& Patahuddin, S. M. (2019). Students' Ability to Solve Mental Rotation Items: Gender Perspective within a Disadvantaged Community. Mathematics Education Research Group of Australasia, 771-778.

Yildiz, B., \& Tüzün, H. (2011). Effects of Using Three-Dimensional Virtual Environments and Concrete Manipulatives on Spatial Ability. Hacettepe University Journal of Education, 41, 498-508. 
Vol. 5, No. 1, Maret 2021 